\title{
Implementasi assessment for learning berbasis higher-order thinking skills untuk menumbuhkan minat baca
}

\author{
Khoiriah Khoiriah $^{1}{ }^{*}$, Tri Jalmo ${ }^{2}$, Abdurrahman Abdurrahman ${ }^{2}$ \\ ${ }^{1}$ SMP Negeri 32 Bandar Lampung. Jl. Darussalam, Susunan Baru, Langkapura, Lampung 35115, Indonesia \\ ${ }^{2}$ Program Studi Magister Keguruan IPA, Fakultas Keguruan dan Ilmu Pendidikan, Universitas Lampung. \\ Jl. Prof. Sumantri Brojonegoro No.1 Gedong Meneng, Bandar Lampung, Indonesia \\ * Coressponding Author. E-mail: khoiriahspd74@gmail.com
}

Received: 2 January 2019; Revised: 8 March 2019; Accepted: 8 December 2020

\begin{abstract}
Abstrak: Penelitian ini bertujuan menumbuhkan minat baca siswa melalui implementasi assessment for learning berbasis higher-order thinking skills (HOTS) dalam pembelajaran ilmu pengetahuan alam (IPA). Desain penelitian menggunakan quasi-eksperimen dengan sampel kelas VIIIC sebagai kelas eksperimen 1 dan kelas VIIID sebagai kelas eksperimen 2 di SMP Negeri 16 Bandar Lampung melalui teknik random sampling. Instrumen penelitian berupa instrumen asesmen HOTS hasil pengembangan dengan kelayakan terjamin validitas teoritis tim ahli dan validitas empiris yang melibatkan 174 siswa kelas IX SMP. Pengumpulan data penelitian memakai lembar angket instrumen skala self regulated learning $(S R L)$ dengan fokus indikator pengukuran minat baca. Analisis data dilakukan secara deskriptif dengan pendekatan kualitatif. Hasil analisis data menunjukkan minat baca siswa tumbuh sebesar 51,23\% pada kelas eksperimen 1 dengan kategori "tinggi" dan 54,56\% kelas eksperimen 2 juga berkategori "tinggi". Pertumbuhan minat baca tertinggi pada kedua kelas eksperimen terdapat pada indikator membaca kembali buku catatan ketika akan menghadapi ulangan sebesar $60,33 \%$, mencari jawaban dengan membaca buku di perpustakaan untuk memecahkan permasalahan tugas/PR tergolong sulit sebesar 55,01\%, akan menonton acara favorit di televisi apabila tugas/PR telah selesai dikerjakan sebesar $54,00 \%$ dan $52,34 \%$ membaca buku teks pelajaran yang dimiliki. Dengan demikian implementasi assessment for learning berbasis HOTS pada pembelajaran IPA mampu menumbuhkan minat baca siswa.
\end{abstract}

Kata Kunci: assessment for learning, HOTS, minat baca

\section{Implementation of assessment for learning based on higher-order thinking skills to fostering student reading interest}

\begin{abstract}
This study aims to foster students' interest in reading through the implementation of assessment for learning based on higher order thinking skills (HOTS) in science learning. The study design used quasiexperimental with samples of class VIIIC as experimental class 1 and class VIIID as experimental class 2 in SMP Negeri 16 Bandar Lampung through random sampling technique. The research instrument in the form of a HOTS assessment instrument was the result of development with the assurance of the expert team's theoretical validity and empirical validity involving 174 junior high school students. The collection of research data using questionnaires on the instrument scale of self regulated learning (SRL) with a focus on measurement indicators of reading interest. Descriptive data analysis with a qualitative approach. The results of the data analysis showed that students' reading interest grew by 51,23\% in the experimental class 1 with the category "high" and 54,56\% in the experimental class 2 also categorized as "high". The growth of the highest reading interest in the two experimental classes was found in the indicator of rereading the notebook when it faced a replication of 60,33\%, looking for answers by reading books in the library to solve difficult assignments / PR problems of 55,01\%, going to watching favorite programs on television when the assignment / PR has been completed by 54,00\% and 52,34\% read the textbooks that are owned. Thus the implementation of HOTS-based assessment for learning in science learning is able to foster students' interest in reading.
\end{abstract}

Keywords: assessment for learning, HOTS, reading interest

How to Cite: Khoiriah, K., Jalmo, T., \& Abdurrahman, A. (2020). Implementasi assessment for learning berbasis higher-order thinking skills untuk menumbuhkan minat baca. Jurnal Inovasi Pendidikan IPA, 6(2), 176-183. doi:https://doi.org/10.21831/jipi.v6i2.22817 
Jurnal Inovasi Pendidikan IPA, 6 (2), 2020 - 177

Khoiriah Khoiriah, Tri Jalmo, Abdurrahman Abdurrahman

\section{PENDAHULUAN}

Secara potensial pembelajaran IPA memiliki peran strategis dalam mempersiapkan sumber daya manusia berkualitas menghadapi tantangan dan kompleksitas persaingan hidup pada era abad 21 . Pembelajaran IPA identik dengan mengembangkan kreativitas dan mengelola pemikiran siswa melalui cara menghubungkan antar fenomena dalam lingkungan hingga memperoleh gagasan atau ide baru untuk memahami objek pengamatan (Tawil \& Liliasari, 2013). Untuk memperoleh pemahaman mendalam mengenai suatu objek siswa perlu memiliki kecakapan pengetahuan. Hal ini tentu berkaitan erat dengan kemampuan membangun pengetahuan baru berdasarkan konsep pengetahuan yang telah diperoleh melalui aktivitas membaca.

Hasil survei UNESCO (United Nations Educational, Scientific and Cultural Organization) merilis keprihatinan terhadap minat baca masyarakat Indonesia yang berada pada urutan 59 dari 61 negara survei dengan hasil perhitungan sebesar $0,001 \%$ atau dari 1000 orang Indonesia hanya ada 1 orang yang terkategori sebagai rajin membaca. Rilis data UNESCO ini menunjukkan rendahnya minat baca masyarakat Indonesia. Lebih mengejutkan lagi hasil analisis data studi yang dilakukan oleh Trends in International Mathematics and Science Study (TIMSS) pada pemetaan tahun 2015 memaparkan siswa Indonesia memperoleh poin literasi sains sebesar 387 yang menempati ranking 45 dari 48 negara partisipan (Mullis, et. al., 2015). Data ini mengungkapkan prestasi literasi sains siswa Indonesia masih tergolong rendah. Fakta prestasi literasi sains yang mengejutkan ini ternyata dialami pula oleh siswasiswa di beberapa negara dunia sebagaimana hasil studi analisis PISA (Programme for International Students Assessment) pada pemetaan tahun 2015 yang menunjukkan masih terdapat 49 dari 72 negara partisipan mempunyai skor prestasi sains di bawah rata-rata skor internasional $(O E C D, 2016)$.

Keprihatinan capaian prestasi literasi sains siswa Indonesia dan beberapa negara dunia antara lain disebabkan rendahnya minat baca pada sebagian besar siswa. Masalah minat baca saat ini menjadi krusial seiring maraknya penggunaan ponsel pada siswa termasuk di SMP Negeri 16 Bandar Lampung. Budaya membaca tidak bisa dipaksakan karena minat baca terlahir melalui kecenderungan yang bersifat individual (Foasberg, 2014). Membaca hakekatnya termasuk proses berpikir kognitif mengenal, memahami, dan menginterpretasikan lambang hingga mempunyai makna (Berardo, 2006). Melalui kebiasaan membaca siswa dapat mengembangkan dan membekali potensi dengan pengetahuan baru yang berimplikasi pada kemampuan pemahaman konsep lebih tinggi (Hidi, 2001; Guthrie, et. al., 2006; Hock, et. al., 2017). Kecenderungan minat baca yang tinggi lama kelamaan dapat mempengaruhi kebiasaan membaca siswa (Hurst, et. al., 2017).

Guru berperan penting dalam menumbuhkan minat baca siswa (Akyol, et. al., 2014). Hal ini dikarenakan ketepatan merancang strategi pembelajaran dapat mempengaruhi minat belajar siswa (Lombardi, et. al., 2017). Dengan minat belajar tinggi lambat laun berdampak positif terhadap minat baca siswa (Asgari, 2017). Guru harus kreatif menyediakan stimulus pembelajaran yang mampu mendorong siswa berkeinginan melakukan aktivitas membaca. Akan tetapi saat ini belum ada penelitian yang berfokus menumbuhkan minat baca siswa dengan mengimplementasikan assessment for learning (AfL) berbasis higher-order thinking skills (HOTS) dalam proses pembelajaran. Penelitian yang telah dilakukan cenderung pada penerapan bahan ajar. Sebagaimana penelitian Asyhari dan Silvia (2016) menerapkan buletin pembelajaran berbentuk buku saku, penelitian Khairoh (2014, p. 519) menggunakan buku cerita IPA bermuatan pendidikan karakter, dan penelitian Purwanto (2013. p.71) yang mengimplementasikan media pembelajaran komik IPA terpadu.

Kualitas asesmen pembelajaran yang diterapkan guru dapat mempengaruhi proses maupun capaian hasil belajar siswa (Taras, 2005; Muchsini, 2015). Mengimplementasikan AfL dalam pembelajaran berarti menerapkan asesmen secara berkelanjutan atau ongoing assessment (Perrotta \& Whitelock, 2017). AfL dapat mendorong terjadinya asesmen interaktif antara guru dan siswa selama pembelajaran (Bennett, 2010). Strategi mengimplementasikan AfL sangat memungkinkan untuk diketahuinya kekuatan maupun kelemahan pembelajaran yang dilakukan guru dan siswa (Chng \& Lund, 2018).

Instrumen AfL berbasis HOTS dalam Taxonomy Bloom revisi dipaparkan sebagai proses kognitif menganalisis $\left(C_{4}\right)$, mengevaluasi $\left(C_{5}\right)$, dan mencipta $\left(C_{6}\right)$ (Narayanan \& Adithan, 2015). Saat ini implementasi AfL berbasis HOTS dalam pembelajaran masih terbilang rendah. Guru lebih sering melatihkan asesmen yang berorientasi pada mengembangkan lower-order thinking skills (LOTS) (Depdiknas, 2008). Sebagaimana hasil analisis data terhadap instrumen asesmen buatan guru IPA SMP Negeri dan 
Swasta di Provinsi Lampung menunjukkan 54,55\% terkategori $\mathrm{C}_{1} ; 81,82 \% \mathrm{C}_{2} ; 27,27 \% \mathrm{C}_{3} ; 18,18 \% \mathrm{C}_{4}$; 9,09\% $\mathrm{C}_{5} ; 9,09 \% \mathrm{C}_{6}$ (Khoiriah, et. al., 2018).

Implementasi AfL berbasis HOTS lebih mengajak siswa berpikir dibandingkan mengingat fakta atau konsep (Nitko \& Brookhart, 2011). Siswa dituntun terlibat proses berpikir kompleks agar dapat membangun kemampuan berpikir kritis, kreatif, logis, reflektif, pemecahan masalah, dan metakognisi (Salbiah, et. al., 2015). Implementasi AfL berbasis HOTS mendorong siswa terbiasa berpikir HOTS menggunakan pemahaman pengetahuan pada konteks baru (Brookhart, 2010).

Kebiasaan berpikir pada konteks baru menantang siswa mampu menerapkan informasi atau ide yang telah diperoleh melalui pembelajaran sebelumnya (Kamarudin, dkk., 2016). Tantangan berpikir HOTS diyakini mendorong siswa melakukan persiapan belajar (Ramos, et. al., 2013). Tetapi sejauh ini berdasarkan hasil analisis studi literatur terungkap belum ada penelitian mengimplementasikan assessment for learning $(A f L)$ berbasis HOTS dalam menumbuhkan minat baca siswa. Sebagian besar penelitian minat baca yang telah dilakukan fokus pada menerapkan bahan bacaan dan mengembangkan program membaca dalam pembelajaran (Guthrie, 2006; Akyol, et. al., 2014; Foasberg, 2014; Hock, et. al., 2017).

Berdasarkan latar belakang di atas telah dilakukan penelitian implementasi assessment for learning berbasis HOTS dalam pembelajaran IPA yang bertujuan untuk menumbuhkan minat baca siswa SMP pada materi sistem peredaran darah manusia. Hasil penelitian ini diharapkan mampu menjadi solusi alternatif dalam mengembangkan gerakan literasi sekolah dan mendukung program penerapan soal HOTS selama proses pembelajaran.

\section{METODE}

Penelitian ini dilaksanakan pada semester genap 2016/2017 di SMP Negeri 16 Bandar Lampung. Subjek penelitian meliputi 2 kelompok siswa yang diambil dari 10 kelompok siswa kelas VIII secara random sampling. Satu kelompok siswa kelas VIIIC sebagai kelas eksperimen 1 dan satu kelompok lainnya kelas VIII D sebagai kelas eksperimen 2. Desain penelitian menggunakan true experimental jenis pretest-posttest control group (Creswell, 2012). Rancangan desain penelitian ditampilkan pada Tabel 1.

Tabel 1. Rancangan Penelitian Pretest-Posttest Control Group Design

\begin{tabular}{ccccc}
\hline Kelompok & Jumlah Siswa & Pretest & Per-lakuan & Posttest \\
\hline Eksperimen 1 & 30 & $\mathrm{O}_{1}$ & $\mathrm{X}$ & $\mathrm{O}_{2}$ \\
Eksperimen 2 & 30 & $\mathrm{O}_{3}$ & $\mathrm{X}$ & $\mathrm{O}_{4}$ \\
\hline
\end{tabular}

$\mathrm{O}_{1}=$ pretest kelas eksperimen $1 ; \mathrm{O}_{2}=$ posttest kelas eksperimen $1 ; \mathrm{X}=$ perlakuan; $\mathrm{O}_{3}=$ pretest kelas eksperimen $2 ; \mathrm{O}_{4}=$ posttest kelas eksperimen 2

Instrumen penelitian terdiri dari perangkat pembelajaran dan pengumpul data. Instrumen perangkat pembelajaran meliputi rencana pelaksanaan pembelajaran dan instrumen AfL berbasis HOTS. Instrumen AfL berbasis HOTS ini sebelum digunakan lebih dahulu telah melalui uji validitas teoritis tim ahli dan validitas empiris melibatkan 174 siswa kelas IX SMP (Khoiriah, et. al., 2018). Instrumen pengumpul data mengadaptasi instrumen skala self regulated learning (SRL) Zimmerman \& Martinez Pons (2002) dengan fokus indikator pada minat baca. Instrumen ini selanjutnya disebut lembar angket minat baca yang diberikan pada siswa di awal dan akhir pembelajaran.

Tabel 2. Lembar Angket Minat Baca

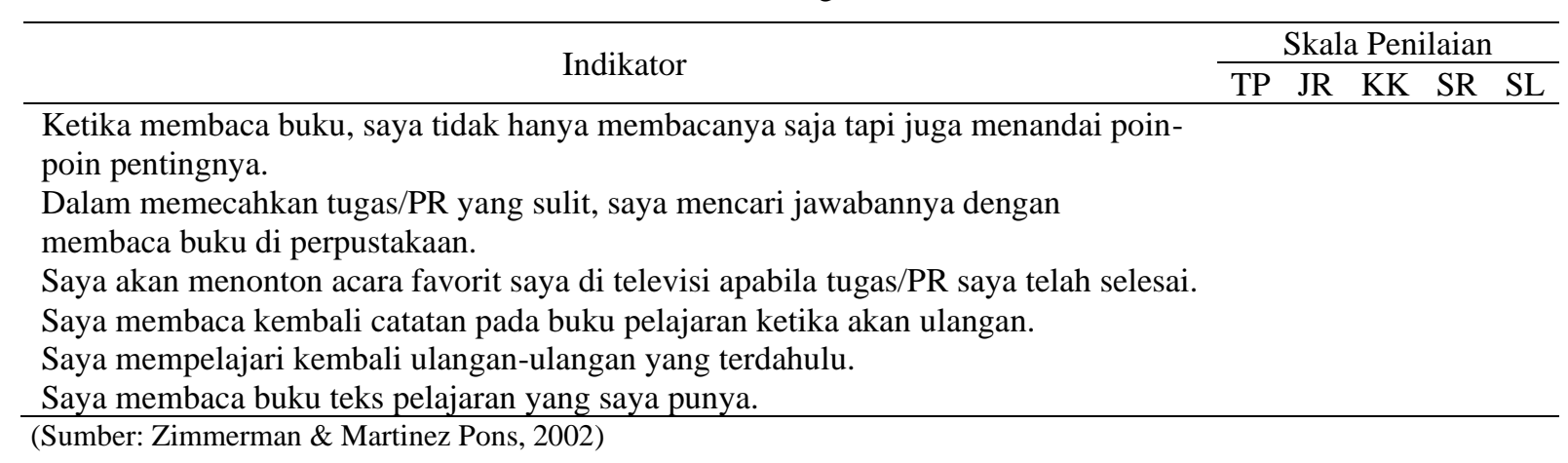


Lembar angket minat baca ini meliputi enam daftar pernyataan berskala Likert dengan lima kriteria penilaian sehingga skor minimal 6 dan skor maksimal 30. Siswa memberikan tanda checklist $(\sqrt{ })$ pada pilihan jawaban. Apabila siswa memilih "tidak pernah (TP)" diberikan skor 1, "jarang (JR)" diberikan skor 2, "kadang-kadang (KK)" diberikan skor 3, "sering (SR)" diberikan skor 4, dan pilihan "selalu (SL)" diberikan skor 5. Adapun instrumen lembar angket minat baca terdapat pada Tabel 2.

Berdasarkan respon jawaban siswa pada lembar angket minat baca dilakukan perhitungan dan menafsirkan hasil analisis dengan menggunakan tafsiran harga persentase minat baca seperti yang ditampilkan pada Tabel 3.

Tabel 3. Kriteria Minat Baca

\begin{tabular}{cc}
\hline Persentase & Kriteria \\
\hline $00,00-25,00$ & Rendah (R) \\
$26,00-50,00$ & Sedang (S) \\
$51,00-75,00$ & Tinggi (T) \\
$76,00-100,00$ & Sangat Tinggi (ST) \\
\hline
\end{tabular}

(Arikunto, 2011)

\section{HASIL DAN PEMBAHASAN}

Data minat baca dalam penelitian ini diperoleh dari hasil penghitungan respon jawaban siswa pada lembar angket minat baca sebelum dan setelah pembelajaran yang mengimplementasikan instrumen AfL berbasis HOTS. Adapun hasil analisis data minat baca siswa dapat dilihat pada Tabel 4 sedangkan pertumbuhan rerata untuk setiap indikator minat baca terdapat pada Tabel 5.

Tabel 4. Minat Baca Siswa pada Kelas Eksperimen 1 dan Kelas Eksperimen 2

\begin{tabular}{|c|c|c|c|c|c|c|c|}
\hline \multirow{3}{*}{ No. } & \multirow{3}{*}{ Indikator } & \multicolumn{6}{|c|}{ Minat Baca (\%) } \\
\hline & & \multicolumn{3}{|c|}{ Kelas Eksperimen 1} & \multicolumn{3}{|c|}{ Kelas Eksperimen 2} \\
\hline & & Awal & Akhir & Tumbuh & Awal & Akhir & Tumbuh \\
\hline 1. & $\begin{array}{l}\text { Ketika membaca buku, saya tidak hanya } \\
\text { membacanya saja tapi juga menandai } \\
\text { poin-poin pentingnya. }\end{array}$ & 42,67 & 92,67 & 50,00 & 42,67 & 85,33 & 42,66 \\
\hline 2. & $\begin{array}{l}\text { Dalam memecahkan tugas/PR yang sulit, } \\
\text { saya mencari jawabannya dengan } \\
\text { membaca buku di perpustakaan. }\end{array}$ & 35,33 & 80,67 & 45,34 & 27,33 & 92,00 & 64,67 \\
\hline 3. & $\begin{array}{l}\text { Saya akan menonton acara favorit saya di } \\
\text { televisi apabila tugas/PR saya telah } \\
\text { selesai. }\end{array}$ & 41,33 & 92,67 & 51,34 & 36,67 & 93,33 & 56,66 \\
\hline & $\begin{array}{l}\text { Saya membaca kembali catatan pada } \\
\text { buku pelajaran ketika akan ulangan. }\end{array}$ & 36,00 & 95,33 & 59,33 & 32,67 & 94,00 & 61,33 \\
\hline 5. & $\begin{array}{l}\text { Saya mempelajari kembali ulangan- } \\
\text { ulangan terdahulu. }\end{array}$ & 41,33 & 92,00 & 50,67 & 41,33 & 89,33 & 48,00 \\
\hline & $\begin{array}{l}\text { Saya membaca buku teks pelajaran yang } \\
\text { saya punya. }\end{array}$ & 42,00 & 92,67 & 50,67 & 37,33 & 91,33 & 54,00 \\
\hline Rata & -Rata Minat Baca (\%) & 39,78 & 91,00 & 51,23 & 36,33 & 90,87 & 54,56 \\
\hline Krite & eria Minat Baca & Sedang & $\begin{array}{l}\text { Sangat } \\
\text { Tinggi }\end{array}$ & Tinggi & Sedang & $\begin{array}{l}\text { Sangat } \\
\text { Tinggi }\end{array}$ & Tinggi \\
\hline
\end{tabular}

Berdasarkan analisis data Tabel 4 dapat diketahui bahwa sebelum implementasi $A f L$ berbasis HOTS minat baca pada siswa kelas eksperimen 1 dan kelas eksperimen 2 rata-rata berkategori "sedang" dan terkategori "sangat tinggi" setelah implementasi AfL berbasis HOTS dengan pertumbuhan rata-rata minat baca sebesar 51,23\% pada kelas eksperimen 1 dan 54,56\% pada kelas eksperimen 2. Pertumbuhan minat baca pada siswa di kedua kelas eksperimen tersebut terkategori "tinggi" (Arikunto, 2011).

Selanjutnya hasil analisis data Tabel 5 mengungkapkan pertumbuhan minat baca siswa kelas eksperimen 1 dan kelas eksperimen 2 yang terkategori "tinggi" terdapat pada indikator dalam memecahkan permasalahan tugas/PR yang tergolong sulit siswa mencari jawaban dengan membaca buku di perpustakaan, siswa akan menonton acara favorit di televisi apabila tugas/PR telah selesai dikerjakan, membaca kembali buku catatan ketika akan ulangan, dan siswa membaca buku teks pelajaran yang dimiliki. 
Jurnal Inovasi Pendidikan IPA, 6 (2), 2020 - 180

Khoiriah Khoiriah, Tri Jalmo, Abdurrahman Abdurrahman

Tabel 5. Pertumbuhan Indikator Minat Baca pada Kelas Eksperimen 1 dan Eksperimen 2

\begin{tabular}{|c|c|c|c|c|c|}
\hline \multirow[b]{2}{*}{ No. } & \multirow[b]{2}{*}{ Indikator } & \multicolumn{3}{|c|}{ Pertumbuhan Minat Baca (\%) } & \multirow[b]{2}{*}{ Kategori } \\
\hline & & $\begin{array}{l}\text { Kelas } \\
\text { Eksp. } 1\end{array}$ & $\begin{array}{l}\text { Kelas } \\
\text { Eksp. } 2\end{array}$ & Rerata & \\
\hline 1. & $\begin{array}{l}\text { Ketika membaca buku, saya tidak hanya membacanya saja } \\
\text { tapi juga menandai poin-poin pentingnya. }\end{array}$ & 50,00 & 42,66 & 46,33 & Sedang \\
\hline 2. & $\begin{array}{l}\text { Dalam memecahkan tugas/PR yang sulit, saya mencari } \\
\text { jawabannya dengan membaca buku di perpustakaan. }\end{array}$ & 45,34 & 64,67 & 55,01 & Tinggi \\
\hline 3. & $\begin{array}{l}\text { Saya akan menonton acara favorit saya di televisi apabila } \\
\text { tugas/PR saya telah selesai. }\end{array}$ & 51,34 & 56,66 & 54,00 & Tinggi \\
\hline 4. & $\begin{array}{l}\text { Saya membaca kembali catatan pada buku pelajaran ketika } \\
\text { akan ulangan. }\end{array}$ & 59,33 & 61,33 & 60,33 & Tinggi \\
\hline 5. & Saya mempelajari kembali ulangan-ulangan terdahulu. & 50,67 & 48,00 & 49,34 & Sedang \\
\hline & Saya membaca buku teks pelajaran yang saya punya. & 50,67 & 54,00 & 52,34 & Tinggi \\
\hline \multicolumn{2}{|r|}{ Nilai Rerata Keseluruhan Indikator } & 51,23 & 54,56 & 52,89 & Tinggi \\
\hline
\end{tabular}

Faktor yang diduga mempengaruhi pertumbuhan minat baca siswa dalam penelitian ini dikarenakan adanya dampak pembelajaran yang timbul selama proses implementasi AfL berbasis HOTS. Implementasi AfL berbasis HOTS dalam penelitian ini dilakukan day to day yang meliputi lima kali pertemuan. Hal ini dimaksudkan untuk mengetahui kualitas pembelajaran menyangkut proses pemahaman pengetahuan maupun kemampuan siswa dalam mengaplikasikan konsep. Implementasi AfL berbeda dengan asesmen pada umumnya yang lebih menitikberatkan pada hasil akhir dari suatu program pengajaran. Guru biasanya melakukan asesmen melalui sederetan kegiatan ulangan seperti ulangan harian, ulangan tengah semester, dan ulangan akhir semester. Asesmen seperti ini lebih untuk keperluan menggelompokkan siswa dalam kategori tertentu (Taras, 2005).

AfL dalam penelitian ini diimplementasikan dengan menerapkan strategi pemberian feedback baik yang dilakukan guru maupun melalui tutor sebaya dalam kelompok-kelompok belajar kolaboratif sehingga berbagai potensi kekuatan maupun titik-titik kelemahan pembelajaran siswa dapat diketahui dengan segera dan lebih efektif. Iklim pembelajaran seperti ini sangat kondusif bagi siswa untuk menerima "masukan" perbaikan sehingga dapat mengurangi tingkat kesalahan dalam memahami suatu konsep. Sebagaimana yang dikemukakan Mulliner \& Tucker (2015); Deeley (2017) bahwa feedback dapat mendorong siswa untuk meningkatkan motivasi belajar, memperbaiki kesalahan bahkan meninggalkan hal-hal negatif yang menjadi titik lemah pembelajaran.

Hal ini senada dengan hasil penelitian Voet, et.al., (2017) yang menyatakan bahwa dengan feedback siswa lebih mampu meningkatkan fokus pembelajaran. Lebih lanjut Hargreaves (2013); Ginkel (2015) menegaskan konsep AfL menggunakan teacher-feedback mampu menciptakan komunikasi interaktif berkaitan dengan pembelajaran siswa sehingga otomatis dapat menjadi sumber utama pengontrol proses belajar mandiri.

Akan tetapi tak dapat dipungkiri keseringan menerima "masukan" perbaikan saat proses pembelajaran tentunya membawa pengaruh terhadap perkembangan psikis siswa. Kenyataan ini dapat menimbulkan perasaan malu dan kecemasan yang tinggi sehingga siswa tertantang melakukan upaya agar mampu mencapai kompetensi yang lebih tinggi. Siswa makin termotivasi memperdalam konsep pengetahuan dengan memperbanyak aktivitas membaca. Kecakapan selama proses pembelajaran diyakini ada korelasinya dengan pemahaman pengetahuan yang dimiliki siswa. Keadaan ini lambat laun menjadi pendorong menumbuhkan minat baca siswa secara individual. Sebagai implikasinya siswa merasa perlu memperbaiki kualitas proses belajar dengan memperdalam pemahaman konsep penting melalui peningkatan aktivitas membaca secara rutin. Hal ini seperti dipertegas Umar (2018); Chng \& Lund (2018) bahwa selain dapat mengetahui perkembangan asesmen secara individual ternyata melalui AfL siswa merasa memegang kendali pembelajaran dan mempunyai keyakinan mampu mencapai keberhasilan lebih tinggi apabila melakukan belajar secara kontinu.

Temuan dalam penelitian ini mengungkapkan minat baca pada siswa tumbuh karena adanya kesadaran diri untuk memperbaiki proses belajar. Seperti yang ditunjukkan pada Tabel 5 beberapa indikator minat baca menunjukkan pertumbuhan dengan kategori "tinggi" antara lain dalam memecahkan permasalahan tugas/PR yang tergolong sulit siswa mencari jawaban dengan membaca buku di perpustakaan, akan menonton acara favorit di televisi apabila tugas/PR telah selesai dikerjakan, membaca kembali buku catatanketika akan menghadapi ulangan, dan membaca buku teks pelajaran yang dimiliki. Fakta 
penelitian ini selaras dengan hasil penelitian Jafaar \& Lin (2017) bahwa AfL yang diterapkan dalam pembelajaran kalkulus mampu mendorong siswa untuk membaca dan memahami materi yang tergolong sulit (27\%), berkeinginan menyelesaikan PR (37\%), dan dapat menggunakan teori maupun konsep yang telah dipelajari pada permasalahan baru (46\%). Lebih lanjut Foasberg (2014) menegaskan minat baca pada siswa cenderung bersifat individual. Oleh sebab itu menumbuhkan kebiasaan membaca pada siswa terasa sulit dilakukan apabila nilai karakter yang berhubungan dengan keberhasilan proses belajar seperti sikap tekun, disiplin, dan bertanggung jawab belum berkembang secara personal. Akan tetapi Tabel 5 justru membuktikan bahwa melalui implementasi AfL berbasis HOTS minat baca siswa pada kelas eksperimen 1 dan kelas eksperimen 2 tumbuh sebesar 52,89\% dengan kategori "tinggi". Temuan ini secara efektif menyiratkan bahwa implementasi AfL berbasis HOTS dapat membangun pembentukan nilai karakter yang lambat laun mempengaruhi kebiasaan membaca pada siswa. Fakta ini senada dengan hasil penelitian Ozsoy, et.al. (2009) bahwa terdapat hubungan yang signifikan antara kebiasaan dan sikap belajar dengan tingkat pencapaian siswa. Lebih lanjut Hidayat \& Qudsiyah (2018) mengemukakan penerapan AfL dalam pembelajaran statistika dapat menumbuhkan sikap tekun, teliti, dan semangat memperoleh pengetahuan lebih tinggi pada mahasiswa. Hasil penelitian Wangge dan Lusyana (2016) mengungkapkan pula implementasi HOTS dalam pembelajaran matematika dapat mengarahkan pembentukan karakter disiplin, tanggung jawab, jujur, dan membangun kemampuan penyelesaian masalah kehidupan sehari-hari.

Hal penting lain yang diduga mempengaruhi pertumbuhan minat baca siswa disebabkan instrumen AfL yang digunakan dalam penelitian ini adalah berbasis HOTS dengan level kognitif C4 (menganalisis), C5 (mengevaluasi), dan C6 (mencipta). Terbukti sajian pengantar soal pada instrumen AfL HOTS yang ditampilkan dalam bentuk data percobaan, tabel, gambar, grafik, diagram, maupun deskripsi fenomena mampu menjadi stimulus pembelajaran bagi siswa. Konten dan konstruksi soal pada instrumen AfL HOTS memberikan peluang kepada siswa untuk memiliki standar yang jelas mengenai tingkat pencapaian kompetensi sehingga dapat dipergunakan sebagai tolak ukur pemahaman terhadap konsepkonsep pengetahuan. Ketika menyelesaikan instrumen AfL HOTS tersebut siswa terlebih dahulu diminta melakukan proses berpikir. Sebagaimana Brookhart (2010) memaparkan HOTS mengajak siswa mampu menerapkan konsep pengetahuan pada implikasi baru ataupun hal-hal baru yang belum pernah diajarkan.

Terungkap secara implisit instrumen AfL berbasis HOTS dalam penelitian ini memaksa siswa memiliki pemahaman sejumlah konsep dasar penting sebagai prasyarat pengetahuan. Hal ini seperti ditegaskan Krathwohl (2002) siswa mampu berpikir pada tahapan lebih tinggi apabila telah menguasai pengetahuan yang berada pada level di bawahnya. Kondisi pembelajaran seperti ini lama kelamaan mendorong siswa harus memperdalam pengetahuan dengan cara meningkatkan aktivitas membaca.

\section{SIMPULAN}

Berdasarkan hasil penelitian dan pembahasan disimpulkan implementasi AfL berbasis HOTS pada pembelajaran IPA terbukti dapat menumbuhkan minat baca siswa dengan kategori "tinggi" yaitu $51,23 \%$ pada kelas eksperimen 1 dan tumbuh sebesar 54,56\% pada kelas eksperimen 2. Pertumbuhan minat baca tertinggi pada kedua kelas eksperimen adalah $60,33 \%$ pada indikator membaca kembali buku catatan ketika akan menghadapi ulangan, sebesar 55,01\% ketika memecahkan permasalahan tugas/PR yang tergolong sulit siswa mencari jawaban dengan membaca buku di perpustakaan, sebesar 54,00\% akan menonton acara favorit di televisi apabila tugas/PR telah selesai dikerjakan dan 52,34\% membaca buku teks pelajaran yang dimiliki.

\section{DAFTAR PUSTAKA}

Akyol, H., Cakiroglu, A. \& Kuruyer, H.G. (2014). A study on the development of reading skills of the students having difficulty in reading: enrichment reading program. International Electronic Journal of Elementary Education, 6(2), 199-212.

Arikunto, S. (2011). Dasar-dasar evaluasi pendidikan. Jakarta: Bumi Aksara.

Asgari, M., Ketabi, S. \& Amirian, Z. (2017). The effect of using interest-based materials on EFL learners performance is reading: focusing on gender differences. Iranian Journal of English for Academic Purposes, 6(2), 1-12. 
Asyhari, A., \& Silvia, H. (2016). Pengembangan media pembelajaran berupa buletin dalam bentuk buku saku untuk pembelajaran IPA Terpadu. Jurnal Ilmiah Pendidikan Fisika Al-BiRuNi,05(1).1-13.

Bennett, R. (2010). Formative assessment: A critical review. Presentation at The Hongkong Institute of Education, China.

Berardo, S. A. (2006). The use of authentic materials in the teaching of reading. The Reading Matrix, 6(2), 60-69.

Brookhart, S. M. (2010). How to assess higher order thinking skills in your classroom. Alexandria, Virginia.

Chng, L. S., \& Lund, J. (2018). Assessment for learning in physical education: The what, why and how. Journal of Physical Education, Recreation and Dance, 89(8), 29-34.

Creswell, J. W. (2012). Planning, conducting, and evaluating quantitative and qualitative research. Lincoln: University of Nebraska.

Deelay, S. J. (2017). Using technology to facilitate effective assessment for learning and feedback in higher education. Assessment and Evaluation in Higher Education, -(-), 1-16.

Depdiknas. (2008). Strategi pembelajaran matematika dan ilmu pengetahuan alam. Direktorat Jendral Peningkatan Mutu Pendidik dan Tenaga Kependidikan, Departemen Pendidikan Nasional. Jakarta.

Foasberg, N. M. (2014). Student reading practices in print and electronic media. College and Research Libraries, 9(-), 705-723.

Ginkel, S.V., Gulikers, J., Biemans, H. \& Mulder, M. (2015). The impact of the feedback source on developing oral presentation competence. Studies in Higher Education, -(-), 1-15.

Guthrie, J.T., Wigfield, A.L., Humenik, N. M., Perencevich, K.C., Taboada, A. \& Barbosa, P. (2006). Influences of stimulating tasks on reading motivation and comprehension. Journal of Educational Research., 99(4), 232-245.

Hargreaves, E. (2013). Inquiring into children's experiences of teacher feedback: Reconceptualising assessment for learning. Oxford Review of Education, 39(2), 229-246.

Hidayat, T. \& Qudsiyah, K. (2018). Assessment for Learning (AfL) dalam pembelajaran statistika dasar. Jurnal Humaniora, 5(2), 733-737.

Hidi, S. (2001). Interest, reading, and learning: theoretical and practical considerations. Educational Psychology Review, 13(3), 191-209.

Hurst, S., Marsh, D., Brown, D. A. \& Forbes, S.A. (2017). Cats, comics, and knausgard: promoting student reading at a UK academic library with a leisure reading collection. Taylor and Francis in New Review of Academic Librarianship, -(-), 1-18.

Hock, M.F., Brasseur-Hock, I.F., Hock, A.J. \& Duvel, B. (2017). The effects of a comprehensive reading program on reading outcomes for middle school students with disabilities. Journal of Learning Disabilities, 50(2), 195-212.

Jafaar, R., \& Lin, Y. (2017). Assessment for learning in the calculus classroom: A proactive approach to engage students in active learning. Internasional Electronic Journal of Mathematics Education, 12(3), 503-520.

Kamarudin, M.Y., Nik, Y., Nik, M. R., Ahmad, H. Y. \& Ghani, K. A. (2016). Inculcation of higher order thinking skills (hots) in arabic language teaching at malaysian primary schools. Journal Scientific Research Publishing.

Khairoh, L., Rusilowati, A., \& Nurhayati, S. (2014). Pengembangan buku cerita IPA terpadu bermuatan pendidikan karakter peduli lingkungan pada tema pencemaran lingkungan. Unnes Science Education Journal, 3(2), 519-527.

Khoiriah, K., Jalmo, T., \& Abdurrahman. (2018). Development of assessment instruments higher order thinking skills on science subjects for students grade eight junior high school. The Online Journal of New Horizon in Education, 8(2), 19-29.

Krathwohl, D. R. (2002). A revision of Bloom's taxonomy: An overview. Theory and Practice, 41(4), 212-218. 
Lombardi, A. R., Izzo, M. V., Rifenbark, G. G., Murray, A., Buck, A., Monahan, J. \& Gelbar, N. (2017). The impact of an online transition curriculum on secondary student reading: a multilevel examination. Career Development and Transition for Exceptional Individuals, 40(1), 15-24.

Muchsini, B. (2015). Integration of higher order thinking skills in assessment instrument accounting computer at higher education. Prosiding ICTTE FKIP UNS, 1(1), 332-336.

Mulliner, E., \& Tucker, M. (2015). Feedback on feedback practice: Perceptions of students and academics. Assessment and Evaluation in Higher Education, -(10), 1-23.

Mullis, I. V. S., Martin, M.O., Foy, P. \& Hooper, M. (2015). TIMMS 2015 International Results. Boston: Lynch School of Education.

Narayanan, S., \& Adithan, M. (2015). Analysis of question papers in engineering courses with respect to HOTS (higher order thinking skills). American Journal of Engineering Education, 6(1), 1-10.

Nitko, A. J., \& Brookhart, S. M. (2011). Educational assessment of student $6^{\text {th }}$ edition. Boston: Pearson Education.

Organisation for Economic Cooperation and Development (OECD). (2016). Performance in mathematics, reading and science.

Ozsoy, G., Memis, A. \& Temur, T. (2009). Metacognition, study habits, and attitudes. International Electronic Journal of Elementary Education, 2(1), 154-166.

Perrota, C., \& Whitelock, D. (2017). Assessment for learning. Technology Enchaned Learning Research Themes, -(-), 127-135.

Purwanto, D., \& Yuliani. (2013). Pengembangan media komik IPA terpadu tema pencemaran air sebagai media pembelajaran untuk siswa SMP Kelas VII. Jurnal Pendidikan Sains e-Pensa, 1(1), hlm.7176.

Ramos, J. L. S., Dolipas, B. B. \& Villamor, B. B. (2013). Higher order thinking skills and academic performance in physics of college students: a regression analysis. International Journal of Innovative Interdisciplinary Research.

Salbiah, M. H., Ruhizan, M. Y. \& Roslinda, R. (2015). A meta-analysis study on the effectiveness of higher order thinking skills (hots) based learning in science and mathematics subjects. Journal of Educational Community and Cultural Diversity.

Taras, M. (2005). Assessment summative and formative some theoretical reflections. British Journal of Educational Studies, 53(4), 466-478.

Tawil, M., \& Liliasari. (2013). Berpikir kompleks dan implementasinya dalam pembelajaran IPA. Makasar: Badan Penerbit Universitas Negeri Makasar.

Umar, A. M. A. (2018). The impact of assessment for learning on students achievement in english for specific purposes. English Language Teaching, 11(2), 15-25.

Voet, M., Gielen, M., Boelens, R. \& De Wever, B. (2017). Using feedback requests to actively involve assessees in paper assessment: effects on the assessors feedback content and assessees agreement with feedback. European Journal of Psychology in Education, 33(1), 145-164.

Wangge, M., \& Lusyana, E. (2016). Higher order thinking skills (HOTS) mathematics untuk mendukung pembentukan karakter siswa. Prosiding Seminar NasionalProdi PGSD dan Prodi BK FKIP Universitas Ahmad Dahlan.

Zimmerman, B. \& Martinez, P. (2002). Becoming a self regulated learner: an overview. Theory into Practice.College of Education. The Ohio State University. 